УДК 615.37:[61:001.8]

DOI https://doi.org/10.11603/2312-0967.2019.3.10391

\title{
ПРОБІОТИКИ З ПОЗИЦІї ДОКАЗОВОЇ МЕДИЦИНИ
}

\author{
І. Л. Чухрай \\ Львівський національний медичний університет імені Данила Галицького \\ iryna_chukhray@ukr.net
}

ІНФОРМАЦІЯ

Надійшла до редакції / Received: 10.07.2019

Після доопрацювання / Revised: 25.07.2019

Прийнято до друку / Accepted: 26.07.2019

\section{Ключові слова:}

пробіотики;

доказова медицина;

Кокранівська бібліотека;

систематичні огляди.

\begin{abstract}
АНОТАЦІЯ
Мета роботи. Здійснити впорядкування даних доказової медицини стосовно застосування пробіотиків, враховуючи ступінь підтвердження їхньої есрективності при профрілактиці та лікуванні різних захворювань.

Матеріали і методи. Матеріал дослідження склали систематичні огляди Кокранівської бібліотеки за період 2006 - 2018 рр., використано методи інсрормаційного пошуку, аналізу та узагальнення.

Результати й обговорення. Систематичні огляди стосовно ефективності та безпеки використання пробіотиків було ранжовано за датою та темою. Показано, що актуальність вивчення ефективності застосування пробіотиків зростає. Встановлено, що найбільша частка систематичних оглядів присвячена застосуванню пробіотиків у гастроентерології.

Підтверджено безпечність проведення пробіотикотерапії та з'ясовано, що для досягнення ефекту, аналогічного до отриманих у рандомізованих клінічних дослідженнях, необхідно використовувати ту ж саму фрорму і дозу пробіотика, як у дослідженні. Позитивний есрект пробіотика, що спостерігається у пацієнтів одного віку, не екстраполюється на пацієнтів іншого віку, а також ефект певного пробіотика не переноситься на інші види та штами пробіотичних мікроорганізмів.

Висновки. На підставі аналізу даних Кокранівської бібліотеки виділено 32 систематичні огляди стосовно ефективності та безпеки використання пробіотиків, які розподілено на чотири групи: з підтвердженою ефективністю; з підтвердженою ефективністю, яка потребує додаткових рандомізованих клінічних досліджень; 3 недостатніми доказами ефективності, але 3 перспективністю подальших рандомізованих клінічних досліджень; 3 не підтвердженою ефективністю. За даними систематичних оглядів першої групи встановлено, що клінічно обґрунтованим напрямком застосування пробіотиків є профрілактика антибіотикоасоційованої діареї та лікування гострої інсрекційної діареї.
\end{abstract}

Вступ. В Україні широко використовуються пробіотики (ПБ), основу яких складають живі мікробні культури чи інактивована пробіотична фрлора. Видовий склад мікроорганізмів, які використовуються для отримання пробіотиків, постійно розширюється [1], тому для підвищення ефективності та безпечності пробіотикотерапії (ПБТ) необхідно враховувати дані доказових баз [2]. Найбільш відомою електронною базою даних з доказової медицини є Кокранівська бібліотека (Cochrane library) [3].

Мета роботи - здійснити впорядкування даних доказової медицини стосовно застосування пробіотиків, враховуючи ступінь підтвердження їхньої ефективності при профрілактиці та лікуванні різних захворювань.

ISSN 2312-0967. Фармацевтичний часопис. 2019. № 3 
Матеріали і методи. Матеріалами дослідження були систематичні огляди (СО), наведені в розділі «Cochrane Evidence» (Кокранівські докази) Кокранівської бібліотеки за період 2006 - 2018 рр., що отримані шляхом введення пошукового слова «Probiotic» (ПБ). Виявлено 40 СО про ПБ, до подальшого дослідження відібрано 32 СО, з них один мав статус «нового» та два - подкаст. Критеріями відбору був пошук усіх рандомізованих клінічних досліджень (РКД) щодо ефективності та безпеки використання ПБ незалежно від методу маскування, статусу публікації і мови. При цьому вилучали СО, які дублювалися, та ті, у висновках яких від- сутня конкретизація застосування. Використано методи інформаційного пошуку, аналізу та узагальнення.

Результати й обговорення. 3 метою оцінки актуальності проблеми та встановлення пріоритетних напрямків досліджень про застосування ПБ СО були нами ранжовані за датою (функція «Sort by Date») (рис. 1) та темою (Health topics) (рис. 2).

3'ясовано, що актуальність вивчення ефективності застосування ПБ зростає, в останні роки в базі Кокрана представлено по 4-6 СО на рік.

За даними рисунка 2, найбільша частка СО присвячена застосуванню ПБ у гастроентерології.

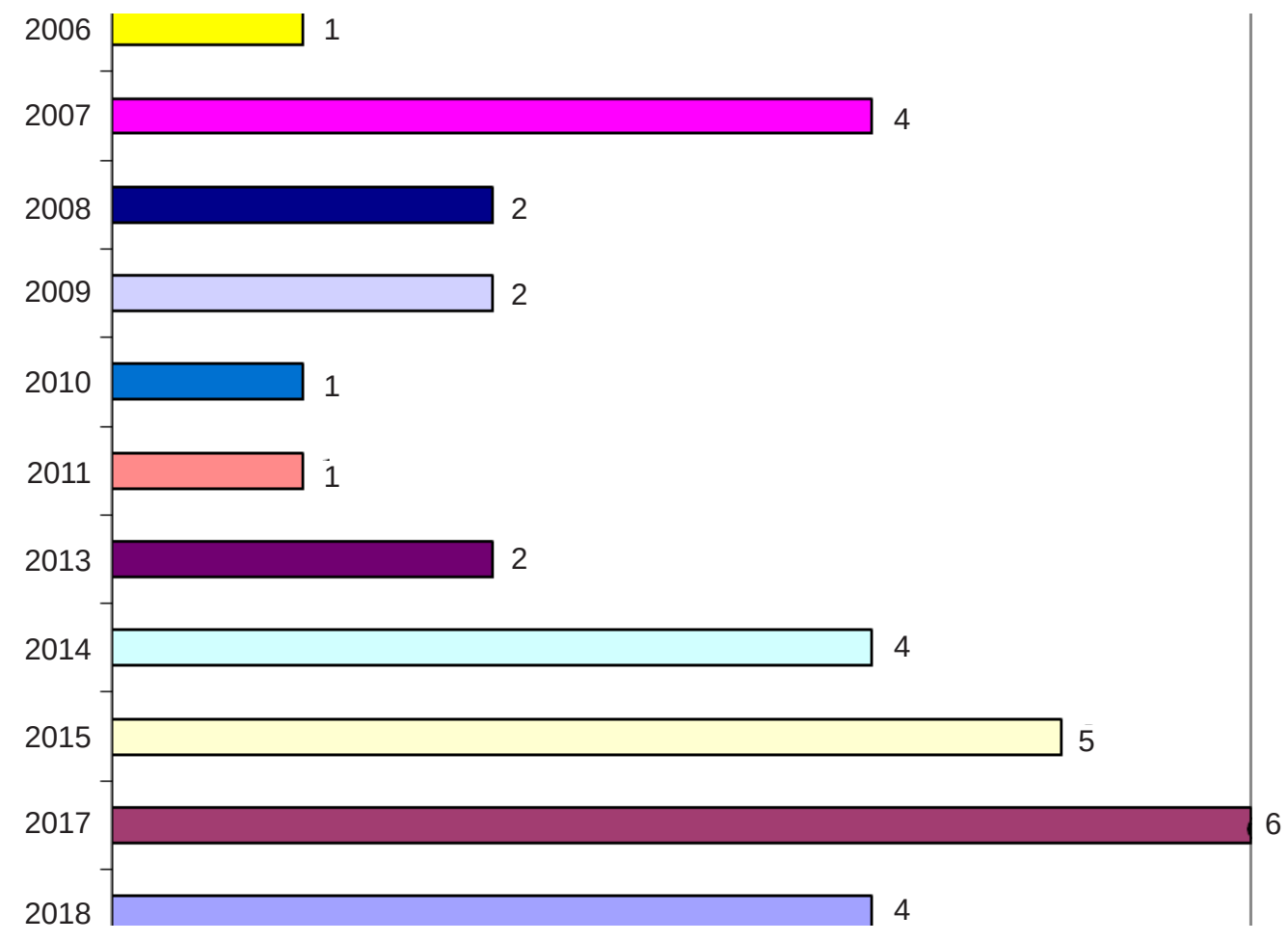

Рис. 1. Розподіл систематичних оглядів стосовно пошукового слова «Probiotic» за роками.

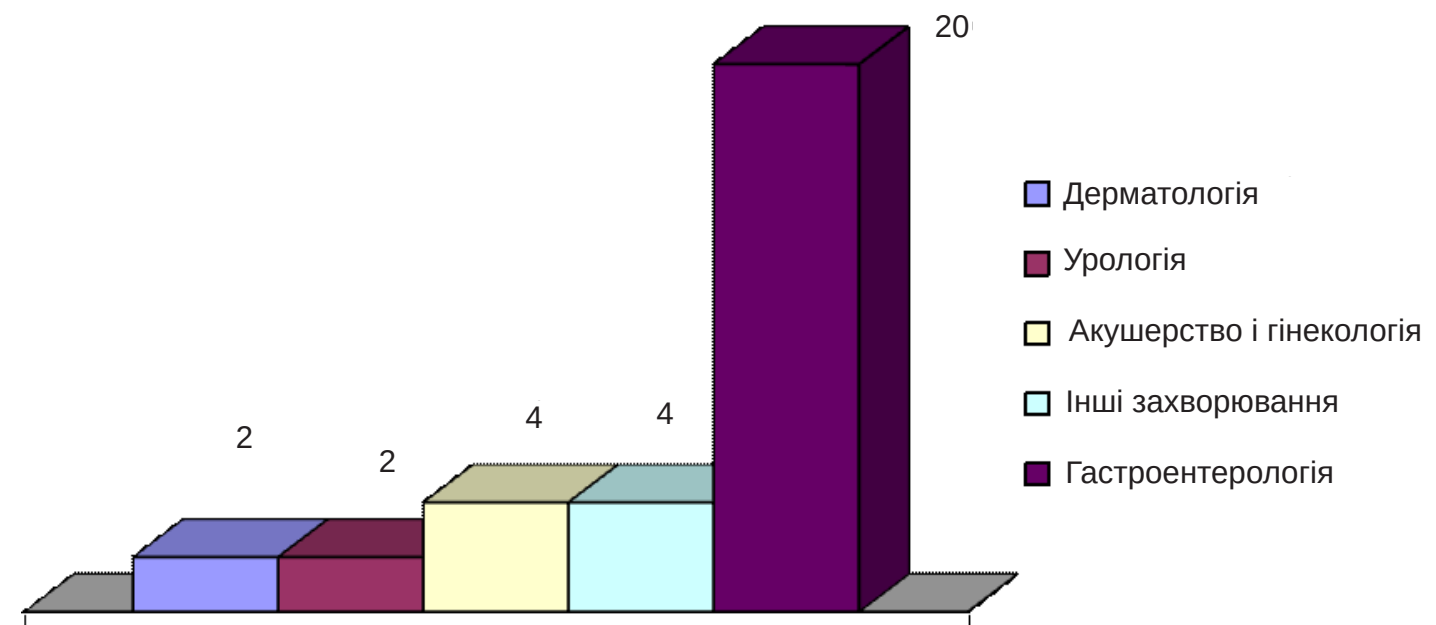

Рис. 2 . Розподіл систематичних оглядів стосовно пошукового слова «Probiotic» за захворюваннями

ISSN 2312-0967. Pharmaceutical review. 2019. № 3 
Досліджувані СО структуровано в чотири групи за доказовістю. До першої віднесено три СО, в яких була підтверджена ефективність застосування ПБ (табл. 1).

До другої групи долучено п'ять СО, які підтверджують ефективність використання ПБ, але встановлена необхідність проведення додаткових РКД для визначення найбільш ефективних ПБ чи їх оптимального дозування або встановлення тривалості терапії тощо:

1. Попередження некротичного ентероколіту в передчасно народжених дітей. Було проведено 24 РКД. Підтверджено, що ентеральні ПБ значно знижують частоту важкого некротичного ентероколіту (стадія II або більша) (20 РКД, $\mathrm{n}=5529 ;$ ВР 0,43; 95 \% ДІ 0,33...0,56) і смертності (17 РКД, $\mathrm{n}=5112$; ВР 0,65, $95 \%$ ДІ 0,52...0,81). Для того, щоб оцінити найбільш ефективні ПБ, тривалість терапії, необхідні подальші порівняльні РКД [7].

2. При гінекологічних захворюваннях. Спостерігалося зниження ризику генітальної інфрекції на 81 \% у групі жінок, що використовували ПБ (2 РКД, n = 88; ВР 0,19; 95 \% ДІ 0,08...0,48) [8]. РКД показали успішний результат лікування бактеріального вагінозу ПБ та оральним метронідазолом (ВР 0,09; 95 \% ДІ 0,03...0,26) і ПБ та естріолом (ВР 0,02; $95 \%$ ДІ 0,00...0,47). Рекомендовано провести РКД більшого розміру з цього питання [9].

3. Лікування та попередження кандидозного вульвовагініту у невагітних жінок. Порівняно з традиційним лікуванням, ПБ можуть збільшити швидкість короткотермінового клінічного (5 РКД; n = 695; ВР 1,14,
95 \% ДІ 1,05...1,24) та мікологічного лікування (7 РКД; $\mathrm{n}=969 ;$ ВР 1,06, 95 \% ДІ 1,02...1,10) та зменшити частоту рецидивів на один місяць (3 РКД; $\mathrm{n}=388$; ВР 0,34; 95 \% ДІ 0,17...0,68). Рекомендовано провести РКД зі стандартизованими методологіями, більш тривалим періодом спостереження та більшим розміром вибірки [10].

4. Рецидивуючий біль в животі у дітей. Встановлено, що діти, які отримували ПБ, повідомляли про більше зниження частоти болю від нуля до трьох місяців після початку лікування ПБ, ніж ті, які отримували плацебо (6 РКД; n = 523; Середня різниця - 0,55; $95 \%$ ДІ -0,98...-0,12). Спостерігалося зменшення інтенсивності болю (7 РКД; $\mathrm{n}=575 ; 95$ \% ДІ -0,85...0,15). Необхідні подальші випробування для вивчення довгострокових результатів, а також для встановлення оптимального штаму та його дозування [11].

До третьої групи включено двадцять СО, в яких РКД були низької якості чи встановлено недостатність доказів, але визначено необхідність проведення наступних РКД для підтвердження ефективності використання ПБ.

1. Для профрілактики:

- інфекцій верхніх дихальних шляхів [12]. Проаналізовано 12 РКД (випробування включали різні штами Lactobacillus та Bifidobacterium) і встановлено, що ПБ сприяють зменшенню кількості осіб, які хворіють на гострі інфекції верхніх дихальних шляхів приблизно на $47 \%$, або тривалість гострого епізоду цього захворювання зменшується приблизно на 45 годин ( $\mathrm{n}=3720 ; 95$ \% ДІ 1,75...2,03; Р <0,001). Використання ПБ також зменшує використання антибіотиків при

\section{Таблиця 1}

Систематизація доказових даних, в яких підтверджена ефективність застосування ПБ

\begin{tabular}{|c|c|c|}
\hline Покази & $\begin{array}{c}\text { Пробіотичні штами, які використовувалися в } \\
\text { рандомізованих клінічних дослідженнях }\end{array}$ & $\begin{array}{l}\text { Кількість РКД та } \\
\text { учасників (n) }\end{array}$ \\
\hline $\begin{array}{l}\text { Просрілактика виникнення } \\
\text { антибіотикоасоційованої діареї } \\
\text { (ААД) у дітей }\end{array}$ & $\begin{array}{l}\text { Bacillus spp., Bifidobacterium spp., Clostridium } \\
\text { butyricum, Lactobacillus spp., Lactococcus spp., } \\
\text { Leuconostoc cremori, Saccharomyces spp., } \\
\text { Streptococcus spp. окремо або в комбінації }\end{array}$ & 33 РКД; $n=6352$ \\
\hline \multicolumn{3}{|c|}{$\begin{array}{l}\text { Результати: доведена есективність Lactobacillus та Saccharomyces boulardii (5 - } 40 \text { млрд кУО/день) для } \\
\text { профрілактики ААД у дітей, які отримували антибіотики (BP 0,46; } 95 \% \text { ДІ 0,35...0,61) [4] }\end{array}$} \\
\hline Лікування гострої інфекційної діареї & $\begin{array}{l}\text { Lactobacillus, } \\
\text { Saccharomyces boulardii }\end{array}$ & 63 РКД; n = 8014 \\
\hline \multicolumn{3}{|c|}{$\begin{array}{l}\text { Результати: ПБ скорочують середню тривалість діареї приблизно на } 25 \text { годин (35 РКД; n = } 4555 ; 95 \% \text { ДІ } \\
\text { 15,9...33,6), а діарею тривалістю чотири або більше днів на } 59 \text { \% (29 РКД; n = 2853; ВР 0,41; } 95 \text { \% ДІ 0,32...0,53) } \\
\text { та частоту випорожнень до двох на день (20 РКД; } \mathrm{n}=2751 ; \text { ВР 0,80; } 95 \text { \% Ді 0,45...1,14). Необхідні додаткові РКД } \\
\text { для уточнення використання конкретних пробіотичних схем у конкретних групах пацієнтів [5] }\end{array}$} \\
\hline $\begin{array}{l}\text { Просрілактика виникнення } \\
\text { Clostridum difficile-асоційованої } \\
\text { діареї }\end{array}$ & $\begin{array}{l}\text { Saccharomyces boulardii або } \\
\text { Lactobacillus acidophilus i Lactobacillus casei }\end{array}$ & 39 РКД; n = 9955 \\
\hline \multicolumn{3}{|c|}{$\begin{array}{l}\text { Результати: ПБ (у дозі від } 10 \text { до } 50 \text { млрд КУО/день) зменшують ризик розвитку цього типу діареї на } 60 \% \\
\text { (n = 8672; ВР 0,40; } 95 \text { \% ДІ 0,3...0,52). У } 26 \text { РКД були оцінені побічні ефекти та встановлено, що ПБ знижують } \\
\text { ризик розвитку побічних ефектів від приймання антибіотиків (спастичний біль у животі, нудоту, лихоманку, м'які } \\
\text { випорожнення, метеоризм і порушення смаку) (ВР 0,80; } 95 \% \text { ДІ 0,68...0,95) [6]. }\end{array}$} \\
\hline
\end{tabular}

ISSN 2312-0967. Фармацевтичний часопис. 2019. № 3 
лікуванні інфекцій верхніх дихальних шляхів. Однак якість доказів була низькою або дуже низькою;

- інфекцій сечової системи у дорослих і дітей [13]. Виявлено незначне зниження ризику рецидиву симптоматичної бактеріальної інфекції сечовивідних шляхів у пацієнтів, які отримували ПБ порівняно з тими, що приймали плацебо (6 РКД, $\mathrm{n}=352 ; \mathrm{BP}$ 0,82; 95 \% ДІ 0,60...1,12);

- гестаційного діабету [14]. Отримані первинні результати зниження частоти виникнення гестаційного цукрового діабету (ВР 0,38; 95 \% ДІ 0,20...0,70). Встановлено перспективність таких РКД;

- виникнення вентилятор-асоційованої пневмонії [15]. Дані РКД свідчать про те, що використання ПБ (Lactobacillus casei rhamnosus, Lactobacillus plantarum, Synbiotic 2000 FORTE, Ergyphilus, комбінація Bifidobacterium longum + Lactobacillus bulgaricus + Streptococcus thermophilus) знижує частоту виникнення вентилятор-асоційованої пневмонії (8 РКД $\mathrm{n}=1083 ; 95 \%$ ДІ 0,52..0,95).

2. При печінковій енцефалопатії [16]. Було проведено РКД, в яких порівнювали ефект від застосування ПБ VSL\#3 (Lactobacillus casei, Lactobacillus plantarum, Lactobacillus acidophilus, Lactobacillus delbrueckii, Bifidobacterium longum, Bifidobacterium breve, Bifidobacterium infantis або Streptococcus thermophilus) 3 есректом від застосування плацебо або відсутністю лікування. Встановлено, що ПБ покращують відновлення та можуть привести до покращення перебігу печінкової енцеоралопатії (10 РКД; n = 585; ВР 0,29; 95 \% ДІ 0,16...0,5), якості життя (3 РКД; $n=115)$, і концентрації в плазмі аміаку (10 РКД; n = 705; 95 \% ДІ 13,17...3,41). Отримані результати були низької якості.

3. Попередження та лікування діареї у хворих на рак, які отримують хіміо- чи променеву терапію (9 РКД; $n=735)$ [17]. Виявлено сприятливий вплив ПБ на запобігання виникнення та вираженості вищенаведеного виду діареї. Позаяк, в РКД були представлені обмежені дані з низькою чи дуже низькою ймовірністю, була визнана перспективність проведення методологічно розроблених випробувань стосовно цієї сорери застосування ПБ.

4. Лікування:

- стійкої діареї в дітей [18]. Отримані дані свідчать, що ПБ зменшують тривалість персистуючої діареї (2 РКД; n = 324; середня різниця - 4,02 дні, $95 \%$ ДІ $4,61 \ldots 3,43)$. Спостерігалося зниження частоти випорожнення при вживанні ПБ у двох РКД. В одному РКД повідомлялося про значне скорочення перебування в лікарні, але чисельність учасників РКД була невеликою;

- активного виразкового коліту [19]. Традиційна терапія в поєднанні з ПБ може забезпечити зниження активності захворювання у пацієнтів з виразковим колітом легкого та середнього ступеня важкості. Лікування проводили з використанням ПБ VSL\#3 (в кіль- кості 300 млрд життєздатних ліофрілізованих бактерій/г); рекомендовано провести додаткові РКД; - екземи [20]. Було проведено 20 РКД за участю 781 учасника з питань ефективності ПБ при лікуванні екземи. Всі учасники випробувань були дітьми. Не було виявлено істотних відмінностей у оцінці важкості екземи між групами, що отримували ПБ та плацеболікування (7 РКД, 588 учасників). За шкалою від 0 до 102 дослідники оцінили ступінь важкості екземи на 2,46 пункти нижче після лікування ПБ (Lactobacillus rhamnosus i Bifidobacterium lactis $2 \times 10^{10} \mathrm{KУО/день}$ або Lactobacillus fermentum VR1-003PCC $2 \times 10^{9} \mathrm{KYO} /$ день), ніж після лікування плацебо (ВР 0,33; 95 \% ДІ $2,53 \ldots 7,45)$. Значну гетерогенність спостерігають між результатами окремих РКД, які можна пояснити використанням різних пробіотичних штамів. На даний час проводяться інші РКД з цієї проблеми.

5. Підтримання ремісії при:

- виразковому коліті [21]. Ефективність вживання ПБ: 75 \% хворих, що приймали ПБ, захворіли на рецидив виразкового коліту протягом року, порівняно 3 $92 \%$ пацієнтів, які отримували плацебо (ВР 0,27; $95 \%$ ДІ 0,03...2,68). 3 огляду на відносно невелике число пацієнтів у аналізі визнано необхідність проведення подальших РКД.

- хронічному паучиті [22]. 85 \% (34/40) пацієнтів, які приймали VLS \# 3 підтримували ремісію через 9 - 12 місяців порівняно з 3 \% (1/36) пацієнтів із плацебо (ВР 20,24, 95 \% ДІ 4,28...95,81). VSL \# 3 також може бути більш ефективним, ніж плацебо, для профрілактики паучиту. Необхідні додаткові РКД, оскільки проведені РКД були низької якості.

6. Включення ПБ до ентерального харчування при гострому панкреатиті знижує ризик смертності (ВР 0,30, $95 \%$ ДІ 0,10...0,84), органну недостатність (ВР 0,74, 95 \% ДІ 0,59...0,92) і місцеві септичні ускладнення (ВР 0,40, 95 \% ДІ 0,22...0,72). Проведені РКД були низької чи дуже низької якості [23].

Перспективність проведення наступних РКД встановлена також стосовно використання ПБ для профрілактики алергічних захворювань, колагенозного коліту, попередження ремісії та лікування індукованої ремісії при хворобі Крона, зменшення побічних ефектів при хіміо- та променевій терапії, попередження передчасних пологів, бактеріального сепсису та ранових ускладнень після трансплантації печінки [8, 24 - 30].

До четвертої групи включено п'ять СО, в яких не встановлено ефективності використання ПБ при лікуванні Clostridum difficile-асоційованого коліту, неалкогольної жирової хвороби печінки та / або стеатогепатиту, профрілактиці захворюваності та смертності у недоношених дітей, захворювань сечової системи в осіб із нейрогенним сечовим міхуром, післяопераційного рецидиву хвороби Крона [31 - 35].

У процесі опрацювання СО:

- з'ясовано, що для досягнення ефекту, аналогічного до отриманих у РКД, необхідно використовувати

ISSN 2312-0967. Pharmaceutical review. 2019. № 3 
ту ж саму форму і дозу ПБ, як у РКД. Позитивний ефрект ПБ, що спостерігається у пацієнтів одного віку, не екстраполюється на пацієнтів іншого віку, а також ефрект певного ПБ не переноситься на інші види та штами пробіотичних мікроорганізмів [5];

- підтверджено безпечність проведення ПБТ, позаяк повідомлення про побічні ефекти застосування ПБ були поодинокими. Серед них найбільш розповсюджені - метеоризм і помірний дискомфорт у зоні живота; важкі (рідко) - сепсис;

- виявлено, що протипоказаннями для застосування ПБ є синдром укороченого кишечника чи центральний венозний катетер (у цих випадках рекомендується використовувати ПБ 3 обережністю), важкі імуносупресорні стани [4].
Висновки. На підставі аналізу даних Кокранівської бібліотеки виділено 32 СО стосовно ефективності та безпеки використання ПБ, які розподілено на чотири групи: $з$ підтвердженою ефективністю; 3 підтвердженою ефективністю, яка потребує додаткових РКД; 3 недостатніми доказами ефективності, але 3 перспективністю подальших РКД; з не підтвердженою ефективністю.

За даними СО першої групи встановлено, що клінічно обґрунтованим напрямком застосування ПБ $є$ просрілактика антибіотикоасоційованої діареї та лікування гострої інфрекційної діареї.

Конфлікт інтересів: відсутній.

Conflicts of interest: author has no conflict of interest to declare.

\title{
PROBIOTICS FROM THE POSITION OF EVIDENCE-BASED MEDICINE
}

\section{L. Chukhray}

\author{
Danylo Halytsky Lviv National Medical University \\ iryna_chukhray@ukr.net
}

The aim of the work. To systematize the data of evidence-based medicine about probiotics, taking into account the degree of confirmation of their effectiveness in the prevention and treatment of various diseases.

Materials and Methods. The research material was systematic reviews of the Cochrane library for the period from 2006 to 2018, methods used: information search, analysis and generalization.

Results and Discussion. Systematic reviews of the effectiveness and safety of using probiotics have been ranked by date and topic. It has been shown that the relevance of studying the effectiveness of probiotics is increasing. It has been established that the largest share of systematic reviews is devoted to the use of probiotics in gastroenterology.

The safety of probiotic therapy has been confirmed and it has been determined that in order to achieve an effect similar to the one obtained in randomized clinical trials, the same form and dose of a probiotic as in the study should be used. The positive effect of probiotics observed in patients of one age is not extrapolated to patients of other age, and the effect of a certain probiotic is not transferred to other species and strains of probiotic microorganisms.

Conclusions. Based on the analysis of the data of the Cochrane library, 32 systematic reviews of the effectiveness and safety of the use of probiotics have been identified, which are divided into four groups: with verified efficacy; with proven efficacy requiring additional randomized clinical trials; with insufficient evidence of efficacy, but with the prospect of further randomized clinical trials; with unverified efficacy. According to the systematic reviews of the first group, it has been established that the clinically justified direction of the use of probiotics is the prevention of antibiotic-associated diarrhea and the treatment of acute infectious diarrhea.

Key words: probiotics; evidence-based medicine; the Cochrane library; systematic reviews.

\section{ПРОБИОТИКИ С ПОЗИЦИИ ДОКАЗАТЕЛЬНОЙ МЕДИЦИНЫ}

\author{
И. Л. Чухрай \\ Львовский национальный медицинский университет имени Данила Галицкого \\ iryna_chukhray@ukr.net
}

Цель работы. Осуществить упорядочение данных доказательной медицины о применении пробиотиков, учитывая степень подтверждения их эффективности при профилактике и лечении различных заболеваний.

Материалы и методы. Материалом исследования были систематические обзоры Кокрановской библиотеки за период 2006 - 2018 гг., использовали методы инорормационного поиска, анализа и обобщение.

Результаты и обсуждение. Систематические обзоры о эффрективности и безопасности использования пробиотиков были ранжированы по дате и теме. Показано, что актуальность изучения эффективности применения пробиотиков

ISSN 2312-0967. Фармацевтичний часопис. 2019. № 3 
растет. Установлено, что наибольшая доля систематических обзоров посвящена применению пробиотиков в гастроэнтерологии.

Подтверждено безопасность проведения пробиотикотерапии и определено, что для достижения эфрфекта, аналогичного к полученным в рандомизированных клинических исследованиях, необходимо использовать ту же форму и дозу пробиотика, как в исследовании. Положительный эффект пробиотика, что наблюдается у пациентов одного возроста, не экстраполируется на пациентов другого возраста, а также эфроект определенного пробиотика не переносится на другие виды и штаммы пробиотических микроорганизмов.

Выводы. На основании анализа данных Кокрановской библиотеки выделено 32 систематических обзора об эфрфективности и безопасности использованияпробиотиков, которые разделеныначетыре группы:сподтвержденной эфффективностью; с подтвержденной эфффективностью, которая требует дополнительных рандомизированных клинических исследований; с недостаточными доказательствами эффрективности, но с перспективностью дальнейших рандомизированных клинических исследований; с не подтвержденной эффрективностью. По данным систематических обзоров первой группы установлено, что клинически обоснованным направлением применения пробиотиков является профилактика антибиотикоассоциированной диареи и лечение острой инфекционной диареи.

Ключевые слова: пробиотики; доказательная медицина; Кокрановская библиотека; систематические обзоры.

\section{Список літератури}

1. Калініченко С. В. Сучасні напрямки створення та удосконалення пробіотиків [Електронний ресурс] / С. В. Калініченко, О. О. Коротких, І. Ю. Тіщенко // Український біофрармацевтичний журнал. - 2016. № 1 (42). - С.4 - 9.

2. Беш Л. В. Проблема дисбактеріозу кишечника в практиці дитячого алерголога: дискусійні питання й можливості їх вирішення [Електронний ресурс] / Л. В. Беш // Здоров'я дитини. - 2012. - № 7 (42). - 133 - 137.

3. Марушко Ю. В. Доказова база застосування окремих пробіотиків при антибіотикоасоційованій діареї В дітей [Електронний ресурс] / Ю. В. Марушко, А. О. Асонов // Здоров'я дитини. - 2018. - № 5.

4. Cochrane. [Electronic resources]. - Available from: http:// www.cochrane.org/search/site/probiotics.

5. Probiotics for the prevention of pediatric antibioticassociated diarrhea [Electronic resources] / J. Z. Goldenberg, L. Lytvyn, J. Steurich [et al.] // Cochrane Database of Syst. Rev. - 2015. - Issue 12. DOI: 10.1002/14651858.

6. Probiotics for treating acute infectious diarrhea [Electronic resources] / S. J. Allen, E. G. Martinez, G. V. Gregorio, L. F. Dans // Cochrane Database of Syst. Rev. - 2010. Issue 11. DOI: 10.1002/14651858.CD003048.pub.

7. The use of probiotics to prevent Clostridium difficile diarrhea associated with antibiotic use [Electronic resources] / J. Z. Goldenberg, C. Yap, L. Lytvyn [et al.] // Cochrane Database of Syst. Rev. - 2017. - Issue 12. DOI: 10.1002/14651858.CD006095.pub4.

8. AlFaleh $\mathrm{K}$. Probiotics for prevention of necrotizing enterocolitis in preterm infants. [Electronic resources] / K. AlFaleh, J. Anabrees // Cochrane Database of Syst. Rev. - 2014. - Issue 4. DOI: 10.1002/14651858. CD005496.pub4.

9. Othman M. Probiotics for preventing preterm labour [Electronic resources] / M. Othman, Z. Alfirevic, J. P. Neilson // Cochrane Database of Syst. Rev. - 2007. - Issue 1. DOI: 10.1002/14651858.CD005941.pub2.

10. Probiotics for the treatment of bacterial vaginosis [Electronic resources] / A. C. Senok, H. Verstraelen,
M. Temmerman, G. A. Botta // Cochrane Data Base of Syst. Rev. - 2009. - Issue 4. DOI: 10.1002/14651858. CD006289.pub2.

11. Probiotics for vulvovaginal candidiasis in non-pregnant women [Electronic resources] / H. Xie, D. Feng, D. Wei [et al.] // Cochrane Database of Syst. Rev. - 2017. Issue11. DOI: 10.1002/14651858.CD010496.pub2.

12. Dietary interventions for recurrent abdominal pain in childhood [Electronic resources] / T. V. NewloveDelgado, A. E. Martin, R. A. Abbott [et al.] // Cochrane Database of Syst. Rev. - 2017. - Issue 3. DOI: 10.1002/14651858.CD010972.pub2.

13. Hao Q. Probiotics for preventing acute upper respiratory tract infections [Electronic resources] / Q. Hao, B. Dong, T. Wu // Cochrane Database of Syst. Rev. - 2015. Issue 2. DOI: 10.1002/14651858.CD006895.pub3.

14. Schwenger E. M. Probiotics for preventing urinary tract infections in adults and children [Electronic resources] / E. M. Schwenger, A. M. Tejani, P. S. Loewen // Cochrane Database of Syst. Rev. - 2015. - Issue 12. DOI: 10.1002/14651858.CD008772.pub2.

15. Probiotics for preventing gestational diabetes [Electronic resources] / H. L Barrett, M. Dekker Nitert, L. S. Conwell, L. K. Callaway // Cochrane Database of Syst. Rev. - 2014. - Issue 2. DOI: 10.1002/14651858. CD009951.pub2.

16. Probiotics for preventing ventilator-associated pneumonia. [Electronic resources] / L. Bo, J. Li, T. Tao [et al.] // Cochrane Database of Syst. Rev. - 2014. - Issue 10. DOI: 10.1002/14651858.CD009066.pub2.

17. Probiotics for people with hepatic encephalopathy [Electronic resources] / R. Dalal, R. G. McGee, S. M. Riordan, A. C. Webster // Cochrane Database of Syst. Rev. - 2017. - Issue 2. DOI:10.1002/14651858. CD008716.pub3.

18. Probiotics for the prevention or treatment of chemotherapy - or radiotherapy-related diarrhoea in people with cancer [Electronic resources] / D. Wei, P. Heus, F. T. van de Wetering [et al.] // Cochrane Database of Sys. Rev. - 2018. - Issue 8. DOI:

ISSN 2312-0967. Pharmaceutical review. 2019. № 3 
10.1002/14651858.CD008831.pub3.

19. Probiotics for treating persistent diarrhoea in children [Electronic resources] / G. Bernaola Aponte, C. Bada Mancilla, N. Carreazo, R. Rojas Galarza // Cochrane Database of Syst. Rev. - 2013. - Issue 8. DOI: 10.1002/14651858.CD007401.pub3.

20. Probiotics for the treatment of active ulcerative colitis [Electronic resources] / P. T. Mallon, D. McKay, S. J. Kirk, K. Gardiner // Cochrane Database of Syst. Rev. - 2007. - Issue 4. DOI: 10.1002/14651858.CD005573.pub2.

21. Probiotics for treating eczema [Electronic resources] / A. Makrgeorgou, J. Leonardi-Bee, F. J. Bath-Hextall [et al.] // Cochrane Database of Syst. Rev. - 2018. - Issue 11. DOI: 10.1002/14651858.CD006135.pub3.

22. Probiotics for maintenance of remission in ulcerative colitis [Electronic resources] / K. Naidoo, M. Gordon, A. O. Fagbemi [et al.] // Cochrane Database of Syst. Rev. - 2011. - Issue 12. DOI: 10.1002/14651858.CD007443. pub2.

23. Therapy for treatment and prevention of pouchitis [Electronic resources] / S. Singh, A. M. Stroud, S. D. Holubar [et al.] // Cochrane Database Syst. Rev. - 2015. - Issue 11. DOI: 10.1002/14651858.CD001176.pub4.

24. Enteral nutrition formulations for acute pancreatitis [Electronic resources] / G. Poropat, V. Giljaca, G. Hauser, D. Štimac // Cochrane Database of Syst. Rev. - 2015. Issue 3. DOI: 10.1002/14651858.CD010605.pub2.

25. Osborn D. A. Probiotics in infants for prevention of allergic disease and food hypersensitivity [Electronic resources] / D. A. Osborn, J. K. H. Sinn // Cochrane Database of Syst. Rev. - 2007. - Issue 4. DOI: 10.1002/14651858. CD006475.pub2.

26. Interventions for treating collagenous colitis [Electronic resources] / T. S. Kafil, T. M. Nguyen, P. H. Patton [et al.] // Cochrane Database of Syst. Rev. - 2017. - Issue 11. DOI: 10.1002/14651858.CD003575.pub6.

27. Probiotics for maintenance of remission in Crohn's disease [Electronic resources] / V. E. Rolfe, P. J. Fortun, C. J. Hawkey, F. J. Bath-Hextall // Cochrane Database of Syst. Rev. - 2006. - Issue 4. DOI: 10.1002/14651858. CD004826.pub2.

28. Butterworth A. D. Probiotics for induction of remission in Crohn's disease [Electronic resources] / A. D. Butterworth, A. G. Thomas, A. K. Akobeng //

\section{References}

1. Kalinichenko SV, Korotkykh OO, Tishchenko IYu. [Contemporary directions of creation and improvement of probiotics]. Ukrainskyi biofarmatsevtychnyi zhurnal. [Internet]. 2016;1(42): 133-7. Ukrainian.

2. Besh LV. [The problem of intestinal dysbacteriosis in the practice of child allergist: controversial questions and the possibilities of their solutions]. Zdorovia dytyny. [Internet]. 2012;7(42). Ukrainian.

3. Marushko YuV, Asonov AO. [Evidence based for the use of specific probiotics for antibiotic-associated diarrhea in children]. Zdorovia dytyny. [Internet]. 2018;5. Ukrainian.

4. Cochrane [Internet]. Available from: http://www.cochrane.org/search/site/probiotics.
Cochrane Database of Syst. Rev. - 2008. - Issue 3. DOI: 10.1002/14651858.CD006634.pub2.

29. Interventions to reduce acute and late adverse gastrointestinal effects of pelvic radiotherapy for primary pelvic cancers [Electronic resources] / T. A. Lawrie, J. T. Green, M. Beresford [et al.] // Cochrane Database of Syst. Rev. - 2018. - Issue 1. DOI: 10.1002/14651858. CD012529.pub2.

30. Nutritional interventions for reducing gastrointestinal toxicity in adults undergoing radical pelvic radiotherapy [Electronic resources] / C. C. Henson, S. Burden, S. E. Davidson, S. Lal // Cochrane Database of Syst. Rev. - 2013. - Issue 11. DOI: 10.1002/14651858.CD009896.pub2.

31. Gurusamy K. Methods of preventing bacterial sepsis and wound complications after liver transplantation [Electronic resources] / K. Gurusamy, M. Nagendran, B. R. Davidson // Cochrane Database of Syst. Rev. 2014. - Issue 3. DOI: 10.1002/14651858.CD006660. pub3.

32. Pillai A. Probiotics for treatment of Clostridium difficileassociated colitis in adults [Electronic resources] I A. Pillai, R. L. Nelson // Cochrane Database of Syst. Rev. - 2008. - Issue 1. DOI: 10.1002/14651858. CD004611.pub2.

33. Probiotics for non-alcoholic fatty liver disease and/ or steatohepatitis [Electronic resources] / F. Lirussi, E. Mastropasqua, S. Orando, R. Orlando // Cochrane Database of Syst. Rev. - 2007. - Issue 1. DOI: 10.1002/14651858.CD005165.pub2.

34. Grev J. Maternal probiotic supplementation for prevention of morbidity and mortality in preterm infants [Electronic resources] / J. Grev, M. Berg, R. Soll // Cochrane Database of Syst. Rev. - 2018. - Issue 12. DOI: 10.1002/14651858.CD012519.pub2.

35. Probiotics for preventing urinary tract infection in people with neuropathic bladder [Electronic resources] / S. Toh, C. L. Boswell-Ruys, B. B. Lee [et al.] // Cochrane Database of Syst. Rev. - 2017. - Issue 9. DOI: 10.1002/14651858.CD010723.pub2.

36. Interventions for prevention of post-operative recurrence of Crohn's disease [Electronic resources] / G. Doherty, G. Bennett, S. Patil [et al.] // Cochrane Database of Syst. Rev. - 2009. - Issue 4. - DOI: 10.1002/14651858. CD006873.pub2.

5. Goldenberg JZ, Lytvyn L, Steurich J, Parkin P, Mahant S, Johnston BC. Probiotics for the prevention of pediatric antibiotic-associated diarrhea. Cochrane Database of Syst Rev. [Internet]. 2015 Dec (12). DOI: 10.1002/14651858.

6. Allen SJ, Martinez EG, Gregorio GV, Dans LF. Probiotics for treating acute infectious diarrhea. Cochrane Database of Syst Rev. [Internet]. 2010(11). DOI: 10.1002/14651858.CD003048.pub3.

7. Goldenberg JZ, Yap C, Lytvyn L, Lo CK, Beardsley J, Mertz D, Johnston BS. The use of probiotics to prevent Clostridium difficile diarrhea associated with antibiotic use. Cochrane Database of Syst Rev. [Internet]. 2017(12).

ISSN 2312-0967. Фармацевтичний часопис. 2019. № 3 
DOI: 10.1002/14651858.CD006095.pub4.

8. AlFaleh $\mathrm{K}$, Anabrees J. Probiotics for prevention of necrotizing enterocolitis in preterm infants. Cochrane Database of Syst Rev. [Internet]. 2014(4). DOI: 10.1002/14651858.CD005496.pub4.

9. Othman M, Alfirevic Z, Neilson JP. Probiotics for preventing preterm labour. Cochrane Database of Syst Rev. [Internet]. 2007(1). DOI: 10.1002/14651858.CD005941. pub2.

10. Senok AC, Verstraelen $H$, Temmerman M, Botta GA Probiotics for the treatment of bacterial vaginosis. Cochrane Data base of Syst Rev. [Internet]. 2009(4). DOI: 10.1002/14651858.CD006289.pub2.

11. Xie H, Feng D, Wei D, Mei L, Chen H, Wang X, Fang F. Probiotics for vulvovaginal candidiasis in non-pregnant women. Cochrane Database of Syst Rev. [Internet]. 2017(11). DOI: 10.1002/14651858.CD010496.pub2.

12. Newlove-Delgado TV, Martin AE, Abbott RA, Bethel A, Thompson-Coon J, Whear R, Logan S. Dietary interventions for recurrent abdominal pain in childhood. Cochrane Database of Syst Rev. [Internet]. 2017(3). DOI: 10.1002/14651858.CD010972.pub2.

13. Hao Q, Dong B, Wu T. Probiotics for preventing acute upper respiratory tract infections. Cochrane Database of Syst. Rev. [Internet]. 2015(2). DOI: 10.1002/14651858. CD006895.pub3.

14. Schwenger EM, Tejani AM, Loewen PS. Probiotics for preventing urinary tract infections in adults and children. Cochrane Database of Syst Rev. [Internet]. 2015(12). DOI: 10.1002/14651858.CD008772.pub2.

15. Barrett HL, Dekker Nitert M, Conwell LS, Callaway LK. Probiotics for preventing gestational diabetes. Cochrane Database of Syst Rev. [Internet]. 2014(2). DOI: 10.1002/14651858.CD009951.pub2.

16. Bo L, Li J, Tao T, Bai Y, Ye X, Hotchkiss RS, Kollef MH, Crooks NH, Deng $X$. Probiotics for preventing ventilatorassociated pneumonia. Cochrane Database of Syst Rev. [Internet]. 2014(10). DOI: 10.1002/14651858.CD009066. pub2.

17. Dalal R, McGee RG, Riordan SM, Webster AC. Probiotics for people with hepatic encephalopathy. Cochrane Database of Syst Rev. [Internet]. 2017(2). DOI:10.1002/14651858.CD008716.pub3.

18. Wei D, Heus P, van de Wetering FT, van Tienhoven G, Verleye L, Scholten RJPM. Probiotics for the prevention or treatment of chemotherapy- or radiotherapy-related diarrhoea in people with cancer. Cochrane Database of Sys Rev. [Internet]. 2018 (8). DOI: 10.1002/14651858. CD008831.pub3.

19. Bernaola Aponte G, Bada Mancilla C, Carreazo N, Rojas Galarza R. Probiotics for treating persistent diarrhoea in children. Cochrane Database of Syst Rev [Internet]. 2013 (8). DOI: 10.1002/14651858.CD007401. pub3.

20. Mallon PT, McKay D, Kirk SJ, Gardiner K. Probiotics for the treatment of active ulcerative colitis. Cochrane Database of Syst Rev. [Internet]. 2007(4). DOI: 10.1002/14651858.CD005573.pub2.

21. Makrgeorgou A, Leonardi-Bee J, Bath-Hextall FJ, Murrell DF, Tang MLK, Roberts A, Boyle RJ. Probiotics for treating eczema. Cochrane Database of Syst Rev. [Internet]. 2018(11). DOI: 10.1002/14651858.CD006135. pub3.

22. Naidoo K, Gordon M, Fagbemi AO, Thomas AG, Akobeng AK. Probiotics for maintenance of remission in ulcerative colitis. Cochrane Database of Syst Rev. [Internet]. 2011(12). DOI: 10.1002/14651858.CD007443.pub2.

23. Singh S, Stroud AM, Holubar SD, Sandborn WJ, Pardi D. Therapy for treatment and prevention of pouchitis. Cochrane Database Syst Rev. [Internet]. 2015(11). DOI: 10.1002/14651858.CD001176.pub4.

24. Poropat G, Giljaca V, Hauser G, Štimac D. Enteral nutrition formulations for acute pancreatitis. Cochrane Database of Syst Rev. [Internet]. 2015(3). DOI: 10.1002/14651858. CD010605.pub2.

25. Osborn DA, Sinn JKH. Probiotics in infants for prevention of allergic disease and food hypersensitivity. Cochrane Database of Syst. Rev. [Internet]. 2007(4). DOI: 10.1002/14651858.CD006475.pub2.

26. Kafil TS, Nguyen TM, Patton PH, MacDonald JK, Chande $\mathrm{N}$, McDonald J. Interventions for treating collagenous colitis. Cochrane Database of Syst Rev. [Internet]. 2017 (11). DOI: 10.1002/14651858.CD003575. pub6.

27. Rolfe VE, Fortun PJ, Hawkey CJ, Bath-Hextall FJ. Probiotics for maintenance of remission in Crohn's disease. Cochrane Database of Syst Rev. [Internet]. 2006(4). DOI: 10.1002/14651858.CD004826.pub2.

28. Butterworth AD, Thomas AG, Akobeng AK. Probiotics for induction of remission in Crohn's disease. Cochrane Database of Syst Rev. [Internet]. 2008(3). DOI: 10.1002/14651858.CD006634.pub2.

29. Lawrie TA, Green JT, Beresford M, Wedlake L, Burden S, Davidson SE, Lal S, Henson CC, Andreyev HN. Interventions to reduce acute and late adverse gastrointestinal effects of pelvic radiotherapy for primary pelvic cancers // Cochrane Database of Syst Rev. [Internet]. 2018 (1). DOI: 10.1002/14651858.CD012529.pub2.

30. Henson CC, Burden S, Davidson SE, Lal S. Nutritional interventions for reducing gastrointestinal toxicity in adults undergoing radical pelvic radiotherapy. Cochrane Database of Syst Rev. [Internet]. 2013(11). DOI: 10.1002/14651858.CD009896.pub2.

31. Gurusamy K, Nagendran M, Davidson BR. Methods of preventing bacterial sepsis and wound complications after liver transplantation. Cochrane Database of Syst. Rev. [Internet]. 2014(3). DOI: 10.1002/14651858. CD006660.pub3.

32. Pillai A, Nelson RL. Probiotics for treatment of Clostridium difficile-associated colitis in adults. Cochrane Database of Syst Rev. [Internet]. 2008(1). DOI: 10.1002/14651858.CD004611.pub2.

33. Lirussi F, Mastropasqua E, Orando S, Orlando R. Probiotics for non-alcoholic fatty liver disease and/or steatohepatitis. Cochrane Database of Syst Rev. [Internet]. 2007(1). DOI: 10.1002/14651858.CD005165.pub2.

34. Grev J, Berg M, Soll R. Maternal probiotic supplementation for prevention of morbidity and mortality in preterm infants. Cochrane Database of Syst Rev. [Internet]. 2018(12). DOI: 10.1002/14651858.CD012519.pub2.

ISSN 2312-0967. Pharmaceutical review. 2019. № 3 
35. Toh S, Boswell-Ruys CL, Lee BB, Simpson JM, Clezy KR. Probiotics for preventing urinary tract infection in people with neuropathic bladder. Cochrane Database of Syst. Rev. [Internet]. 2017(9). DOI: 10.1002/14651858.CD010723.pub2.
36. Doherty G, Bennett G, Patil S, Cheifetz A, Moss AC. Interventions for prevention of post-operative recurrence of Crohn's disease. Cochrane Database of Syst Rev. [Internet]. 2009(4). DOI: 10.1002/14651858.CD006873. pub2.

\section{Відомості про автора:}

Чухрай І. Л. - асистент кафедри організації та економіки фармації, Львівський національний медичний університет імені Данила Галицького, Львів, Україна. E-mail: iryna_chukhray@ukr.net, ORCID 0000-0002-4122-2182

Information about the author:

Chukhray I. L. - assistant of the Organization and Economics of Pharmacy Department, Danylo Halytsky Lviv National Medical University, Lviv, Ukraine. E-mail: iryna_chukhray@ukr.net, ORCID 0000-0002-4122-2182 